\title{
Possible Bornu Basin Hydrocarbon Habitat-A Review
}

\author{
John Adeyinka Adekoya ${ }^{1}$, Peter Sunday Ola $^{2}$, Solomon Ojo Olabode ${ }^{2}$ \\ ${ }^{1}$ Department of Geological Sciences, Osun State University, Osogbo, Nigeria \\ ${ }^{2}$ Department of Applied Geology, Federal University of Technology, Akure, Nigeria \\ Email: yinkadekoya2002@yahoo.com, psolang@yahoo.com, soolabode@futa.edu.ng, \\ bodesolomon@yahoo.com
}

Received 14 April 2014; revised 12 May 2014; accepted 8 June 2014

Copyright (C) 2014 by authors and Scientific Research Publishing Inc.

This work is licensed under the Creative Commons Attribution International License (CC BY). http://creativecommons.org/licenses/by/4.0/

\section{Abstract}

An attempt is made in this article to examine and assess the possible petroleum habitat in the Bornu Basin, which is the Nigerian portion of the Mega-Chad Basin that has been found to host oil and gas in commercial quantities in Niger, Chad and Cameroon. The presence of three of the fundamental geological factors (source rock, reservoir rock and seal/trap) for commercial hydrocarbon accumulation was assessed in the light of existing information. Available geochemical information reveals that the shales of the Bima, Gongila and Fika Formations in the Bornu Basin contain sufficient organic matter for hydrocarbon generation. Limited existing geochemical data suggest that the quantity and quality of the organic matter in the shales vary widely with the TOC of most samples ranging from $0.54 \mathrm{wt} \%-1.25 \mathrm{wt} \%$ and the $\mathrm{HI}$ from $11-173.80 \mathrm{mg} / \mathrm{g}$ in intervals with Tmax in the range of $365^{\circ} \mathrm{C}-519^{\circ} \mathrm{C}$. In addition, the kerogen type is predominantly type III with minor type II, thus suggesting a predominant gas prone basin. Possible reservoir rocks occur as sand/sandstone beds within the Bima, Gombe, and Kerri-Kerri, as well the Gongila Formation which also contains much shale and limestone. Both stratigraphic and structural trapping conditions exist in the Bornu Basin. The structural traps were presumably formed during the widespread Santonian tectonic inversion that affected the entire Mega-Chad Basin. It is suggested that deeper drilling into the sands and sandstone of the untested Bima Formation that could host hydrocarbon of commercial quantities, as evidenced by the discoveries at deeper depths in the neighbouring Termit Basin, was desirable.

\section{Keywords}

Organic Geochemistry, Bornu Basin, Source Rock, Reservoir, Trap 


\section{Introduction}

For commercial accumulation of hydrocarbon to occur in any basin, certain parameters must not only be available but also form an interplay that would create a geological set-up for the formation and entrapment of the hydrocarbon. Prominent among the parameters are source rock, reservoir rock and seal. Accurate assessment of these parameters is important in reducing exploration risk. Exploration work in the Bornu basin had spanned over four decades with fruitless result in spite of major discoveries within the other basins in the Mega-Chad Basin and the West and Central African Rift System (WCARS) in general.

Geological studies of the Bornu Basin started about a century ago [1]. Since then, several published reports [2]-[6] have been written on this basin. These reports and unpublished ones, including proprietary information, were consulted to achieve our aim. In this article, the results of some key geochemical parameters of samples from outcrop as well as from ditch cuttings of 8 deep wells and 10 shallow wells at the fringes of the Bornu Ba$\sin$ [7]-[10] were synthesised to assess the maturation level of the lithostratigraphic units in the basin.

The intent of this paper is to carry out a review of the existence of the conditions in the Bornu Basin-one of the basins of the Mega-Chad Basin. The aim is to assess possible occurrence of fundamental geological parameters for commercial hydrocarbon accumulation and thereafter suggest areas of further research that could serve as guide to subsequent exploratory work in the basin.

\section{Geological Setting}

\subsection{Tectonic Setting}

The Mega-Chad Basin is a large continental basin in the Central West Africa (Figure 1) that covers a total area of about 2,335,000 $\mathrm{km}^{2}$ [11]-[13]. The basin straddles five countries, namely, Nigeria, Niger, Chad Republic, Cameroon and Central Africa Republic. The south western sector of the Mega-Chad Basin, known as the Bornu Basin in Nigeria, which is about one-tenth of the total Mega-Chad Basin, joins the northeastern most part of a SSW-NNE trending Benue Trough (Figure 2). The Benue-Chad axial trough is believed to be the third and failed arm of a triple-junction rift system that preceded the opening of the South Atlantic during the Early Cretaceous, and the subsequent separation of the African and South American continents [14]. Although intercepted by a discontinuous line of granitic basement inliers, the Zambuk ridge, the Chad and Benue basins are presumed to be related genetically to the West and Central African Rift system (WCARS) described by [17] and [3]. In fact, aaccording to [15] [18]-[20], all the basins in the WCARS form contemporaneously with the geodynamic evolution of the African plate throughout the Phanerozoic. They all experienced initial extensional tectonics with intermittent periods of less influential compressive tectonism and magmatism. [21] noted that structural geometries traditionally interpreted as positive "flower" structures in areas of known transpression/strike slip fault are revealed as evidence of inversion structures in the basin. This view could be important when considering hydrocarbon risks and prospectivity in a basin. Evidence of magmatic activities in the Mega-Chad Basin is manifest in the occurrence of Tertiary volcanics and other igneous intrusives in the Bornu and Termit Basins.

The Bornu and Benue Basins are parts of the same dominant NE-SW rift system which, according to [14], formed another triple junction in the Lake Chad area with two ill-fated arms that are now preserved as the NWSE and NNE-SSW to NS trends. The two basins are characterised by tension-induced basement tectonics and by zigzag pattern of faulting. The most common structural features in the basin are horsts and grabens, buried hills and intrusive volcanics. Faults are predominantly tensional and basement involved [5]. The majority of these faults terminate beneath a regional angular unconformity at the boundary between the Cretaceous and Tertiary. Movements along the faults may be strike-slip, with induced compressional folds such as drag folds or positive flower structures.

\subsection{Stratigraphy}

The sediments deposited within the rift system had been divided into the following lithostratigraphic units from bottom to top (Figure 3): the Bima, Gongila, Yolde, Fika, Gombe, Kerri-Kerri and Chad Formations. The Bima Formation unconformably overlies the Precambrian basement and is generally composed of feldspathic, coarse grained sandstones, with beds of quartz pebbles and some layers of shale. These sediments are mainly continental and vary in age from Albian to Cenomanian [5]. Sedimentary structures present include cross-bedding, ripple marks and convolute lamination. The Gongila Formation represents transitional calcareous deposits, which mark 


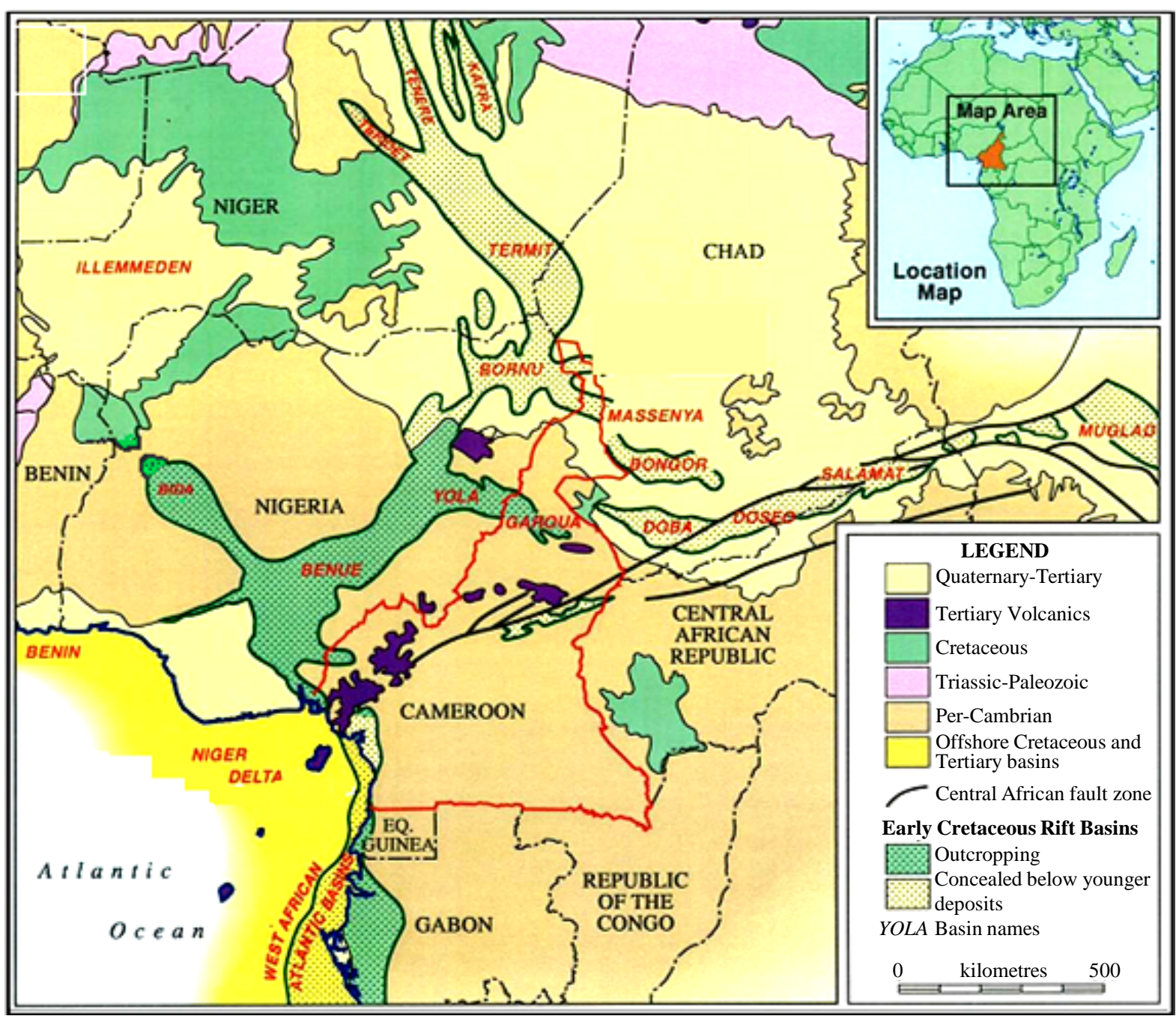

Figure 1. Regional map showing the location of Chad and other neighbouring basins [15].

the onset of marine incursions into the Bornu Basin. It comprises a sequence of alternating sandstone and shale with fossiliferous limestone beds, which mark the boundary with the underlying Bima Formation. The limestone of lower Turonian age is overlain by sandstone. Fika Formation is made up of blue-grey shales, with irregular limestone layers. Coniacian to Santonian age was assigned to this formation. From outcrop and shallow borehole studies [22] the Formation consists of rare basal conglomerate, grit, sandstone and clay. While [5] recognized the Gombe Formation to consist of sandstone, siltstone, and clay with coal beds (Figure 3), [10] found the formation missing in some wells (Kanadi-1, Albarka-1, Gaibu-1 and Kasade-1). Between Gombe and Kerri-Kerri Formations an unconformity was observed by [23] and [8]. Chad Formation consists mainly of fine to coarse grained sands, siltstones, diatomite, clays and blue-grey shales. The Kerri-Kerri and Chad Formations overlie the Cretaceous formations and constitute the Tertiary sediments [6] [24] of the Bornu Basin.

\section{Factors Controlling Petroleum Occurrence}

So far, only insignificant gas has been found in the Bornu Basin. This was encountered in the Kinasar-1 well [13] during the NNPC exploration campaign of the nineties. Certainly, this is a good pointer to the presence of hydrocarbon in the Bornu basin. For a given prospective basin such as the Bornu Basin, it is important to assess the availability and spatial concurrence of the key geological factors (source rock, reservoir rock and seal/trap) recognised as essential for petroleum accumulation in the basin. To start with, a brief review of these factors, which can bring geological success, is considered necessary and therefore first discussed below. 


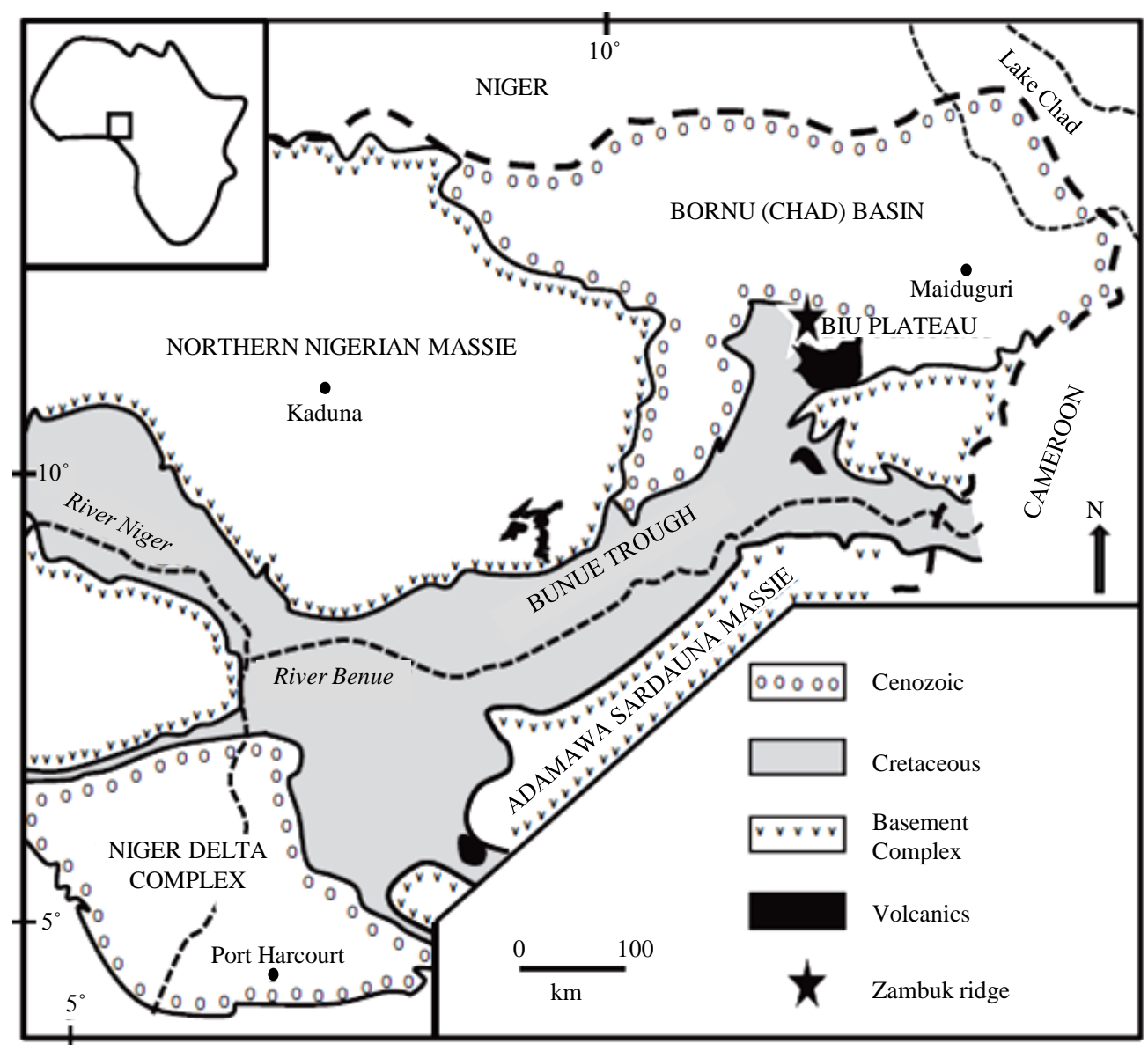

Figure 2. Geological map of Nigeria showing Bornu basin [16].

\subsection{Source Rock}

One of the essential aspects of organic geochemical studies is to determine availability of source rock in a prospective basin. Three major parameters routinely determined are the quality, the quantity and the maturity of the organic matter in fine grained rock sequences, usually shale and limestone. Several geochemical indicators are available for doing these. A fourth parameter, which so far has not been studied in the Chad basin, is expulsion efficiency of the source rock.

\subsubsection{The Quantity of the Organic Matter}

The quantity of the organic matter in a source rock is measured in terms of the total organic carbon (TOC) in the rock. This is carried out on any rock sample to determine its adequacy to generate commercial quantity of hydrocarbon. It is measured as percentage total organic carbon (TOC). The minimum TOC for shale and limestone to generate hydrocarbon is $0.5 \mathrm{wt} \%$ and $0.3 \mathrm{wt} \%$, respectively [25].

\subsubsection{The Quality of the Organic Matter}

Several geochemical indices for assessing the capability of organic matter in a rock to generate oil and/or gas of commercial value include hydrogen index (HI) and type of macerals constituting the kerogen isolated from the fine grained rocks. Hydrogen index is commonly derived from the Rock-Eval pyrolysis results of the amount of hydrocarbon already generated (usually denoted S2) vs. TOC and measured in terms of mgHC/g TOC. Rocks with HI above $300 \mathrm{mg} / \mathrm{g}$ TOC will produce oil and gas, those between 150 and 50 will produce gas, whereas rocks with HI of less than 50 are inert. Similarly, kerogens that are very rich in liptinite would generate oil. Those that are very rich in exinite have genetic potential for oil and gas while those that are predominantly vitrinite will generate gas. 


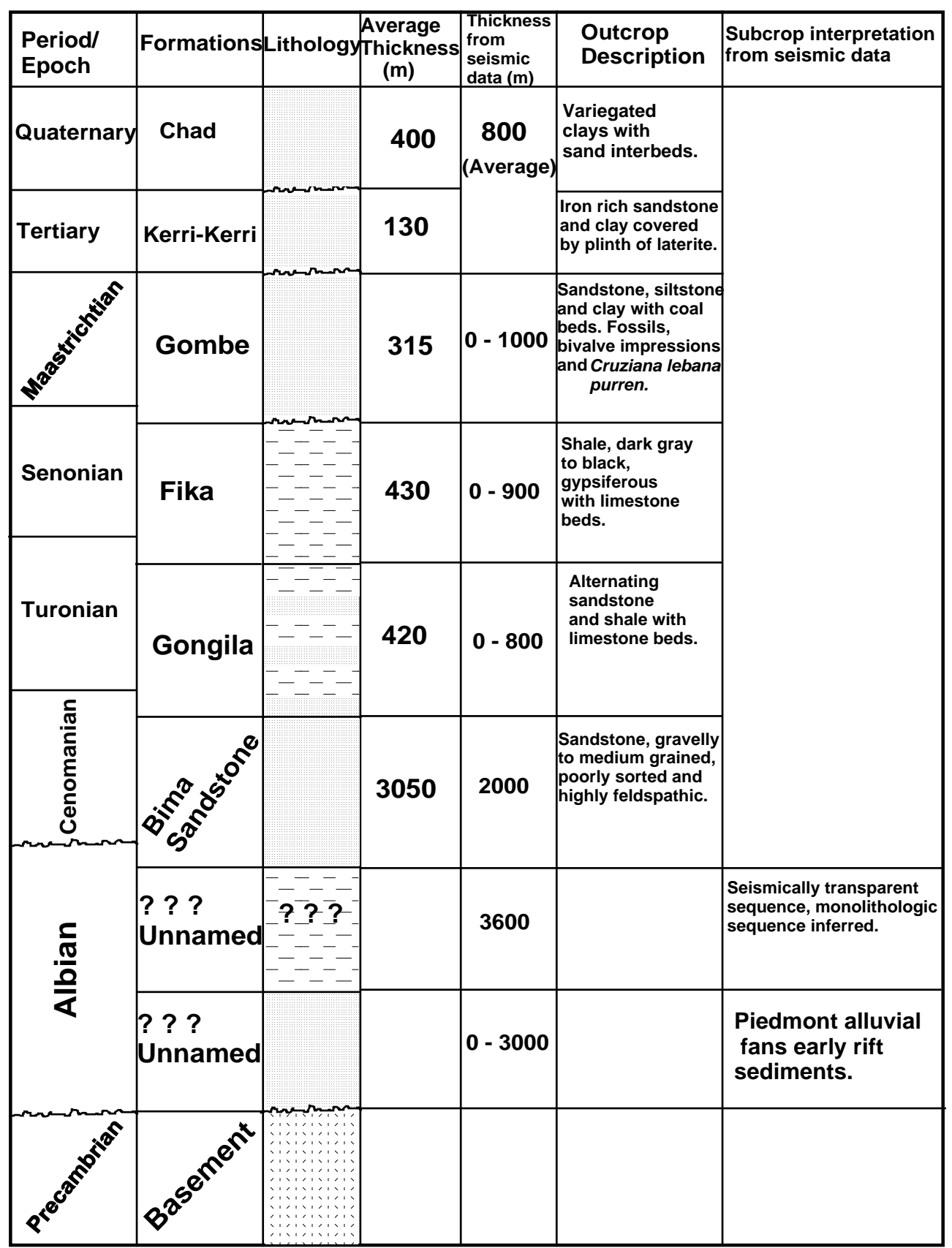

Figure 3. Stratigraphic chart of the Bornu Basin [5].

\subsubsection{Maturity of the Organic Matter}

The thermal evolution of source rock involves three stages: diagenetic, catagenetic and metagenetic which correspond respectively to immature, mature and spent kerogen-the precursor for petroleum. Commonly used indices for determining these stages include vitrinite reflectance (VR) measurement and Tmax determination. Vitrinite reflectance is an optical technique which measures the amount of visible light reflected from the vitrinite materials in kerogen in order to determine source rock maturity. The oil generation window is generally accepted to be between the VR levels of $0.60 \%$ and $1.35 \%$, while values as low as $0.45 \%$ could lead to the generation of immature oil or condensate. Few published studies (e.g. [8] have vitrinite data for the Chad basin probably owing to paucity of phytoclasts (especially vitrinite) and palynomorphs [16].

[26] defines Tmax as the pyrolysis temperature at which the maximum amount of hydrocarbon is released by 
kerogen. It is used to estimate the thermal maturity of sedimentary basins. Tmax is dependent on the cracking kinetics of the organic matter and is correlated with the type of organic matter: lacustrine (Type I), marine (Type II) and continental (Type III and IV). The relationship between Tmax and different stages of oil and gas formation zones varies with the type of organic matter. However Type III is the most reliable in estimating the degree of maturation [27]. Thus the beginning of the oil formation is characterized by Tmax in the range of $430^{\circ} \mathrm{C}-$ $435^{\circ} \mathrm{C}$, whereas the transition oil-gas zone is fixed at $\mathrm{Tmax} \sim 465^{\circ} \mathrm{C}$ [27]. Tmax below 430 suggests immature sediments.

\subsubsection{Geothermal Gradient}

One of the primary factors that affects rate of maturation of organic matter is temperature, which is usually measured in terms of geothermal gradient. Geothermal gradients have been studied in the Bornu Basin. [28] reported values that range between $2.2^{\circ} \mathrm{C} / 100 \mathrm{~m}$ and $5.3^{\circ} \mathrm{C} / 100 \mathrm{~m}$. These values were considered to be very favourable for hydrocarbon generation when compared with those of the Niger delta $\left(1.3^{\circ} \mathrm{C} / 100 \mathrm{~m}\right.$ to $5^{\circ} \mathrm{C} / 100 \mathrm{~m}$, [29]). However, when temperature is traded with time and the Arrhenius equation is applied, the sediments in the Niger delta are younger and cannot be equated to those of the Bornu Basin. In another study, using bottom hole temperature data derived from the wireline log of 21 wells in the Bornu Basin, [30] computed an average regional geothermal gradient of $3.4^{\circ} \mathrm{C} / 100 \mathrm{~m}$ from a range of $3.0^{\circ} \mathrm{C} / 100 \mathrm{~m}$ to $4.4^{\circ} \mathrm{C} / 100 \mathrm{~m}$ and suggested that the average depth to the floor of oil generation in the basin is $3626 \mathrm{~m}$. The different lithostratigraphic units consisting of different lithologies making-up the sequences in the Bornu Basin may not make the deduced oil floor (3626 m), which was computed using monogeothermal gradient, all that correct. In a related study, [31] showed that there is variation in the thermal conductivities (from 1.70 to $3.11 \mathrm{Wm}^{-1} \cdot{ }^{\circ} \mathrm{C}^{-1}$, with an average value of 2.35 $\mathrm{Wm}^{-1} \cdot{ }^{\circ} \mathrm{C}^{-1}$ ) and heat flow (mean heat flow from 63.6 to105.6 $\mathrm{mWm}^{-2}$, with a simple average of $80.6 \mathrm{mWm}^{-2}$ ) both vertically and laterally within the basin. Thermal conductivity is one of the factors that controls geothermal gradient and as such there is the need to re-compute geothermal gradient that can be used to accurately determine the numerical geochemical data of the Bornu Basin.

Volcanic activities of 10 Ma to Recent have been reported [32] to also occur in some parts of the Mega-Chad Basin where oil has been found. Magmatic activities postdating hydrocarbon accumulation could lead to outright metagenetic breakdown of formed hydrocarbon. As a result of this, the assumption that the oil of the Bornu Basin could have been baked needs further study.

\subsection{Reservoir Rock and Seal}

In order to have a hydrocarbon producing reservoir, there must be a body of rock having sufficient porosity $(\varphi)$ to contain the reservoir fluids and permeability $(\mathrm{k})$ to permit their movement. These porous formations, usually sands/sandstones, carbonates with cavities and highly fractured or weathered basement rocks, have to be sealed in such a way that the only method of escape for the fluids is through the wellbore. One more important critical factor, which needs to be considered, is presence of some natural driving force within the reservoir, usually gas or water, to allow the fluids to move to the surface.

\section{Assessment of Factors Controlling Petroleum Occurrence in the Bornu Basin}

It is desirable to assess the Bornu basin on the basis of available geological, geophysical and geochemical information that can indicate the possible existence of the foregoing key factors which normally determine the formation and retention of petroleum in any basin. This appraisal is aimed at identifying and understanding appropriate habitat for petroleum in the Bornu Basin with a view to isolating areas of high prospectivity for follow-up detailed investigations.

\subsection{Source Rock Availability in the Bornu Basin}

In this section, attention is focused on the occurrence of potential source rock in the Bornu Basin. The suitability of the shales within the sedimentary sequences of the basin as source rocks is discussed in the light of limited available geochemical parameters. These parameters are the total organic carbon (TOC), Tmax, hydrogen index (HI), vitrinite reflectance and SOM/TOC (mg/g) and SHC/TOC) (mg/g). The following discussion is based on the shale-bearing lithostratigraphic units (Figure 3) of the basins. 


\subsubsection{Fika Formation}

Available data (Figure 4, Table 1) reveal that the upper and lower horizons of Fika Formation contain sufficient organic matter for hydrocarbon generation. The TOC is as high as 2.15 wt\% in Ziye-1 well. Except in Upper Fika in Kasade -1well (Table 1) where the Tmax is low (424), the Tmax is generally higher (Table 1) than the minimum of between 430 and 435 required for the catagenetic breakdown of organic matter for hydrocarbon generation. Unfortunately, the HI within the Fika Formation appears generally low except in Murshe-1well where a value of 133 is recorded. At shallow depths $(60-390 \mathrm{~m})$ where the Fika shale was penetrated at the fringes of the basin, the shale has a high TOC (av. $0.8 \mathrm{wt} \%$ ) but the SHC/TOC values are well below $10 \mathrm{mg} / \mathrm{g}$ (Table 2) suggesting immaturity of the rock for hydrocarbon generation. Similarly in the other shallow wells tested [20] the average of the TOC within the Fika Shales falls between 0.52 and $0.60 \mathrm{wt} \%$ (Table 3) which could be considered marginal for hydrocarbon generation. The Tmax values of samples from the shallow wells fall below $430^{\circ} \mathrm{C}$ and the $\mathrm{HI}$ values are too low for any oil generation (Table 2). Another result [31] from shallow boreholes at the farther edge of the Bornu Basin shows that the Fika Shales occurring at the depth range of less than $300 \mathrm{~m}$ has sufficient quantity of organic matter for hydrocarbon generation but low vitrinite reflectance values (Table 3). These data also suggest that the kerogen type in the basin could be type 111 or $1 \mathrm{~V}$. However, in a related study, [16] pointed out that $87 \%$ of 153 samples from Fika and Gongila Formations studied under transmitted white light have more than $90 \%$ amorphous organic matter, suggesting marine origin for the organic matter within the two formations.

\subsubsection{Gongila Formation}

Available TOC data on Gongila Formation penetrated by eight exploratory wells (Table 1) strongly indicate that the formation contains sufficient organic matter for hydrocarbon generation. Similarly the TOC derived from shallow boreholes (Table 2) having average values of $0.54 \mathrm{wt} \%-0.91 \mathrm{wt} \%$ also confirms that the upper part of the formation contains adequate organic matter for hydrocarbon generation. However the HI values of the formation generally fall below the minimum $50 \mathrm{mg} \mathrm{HC/g}$ TOC except in the case of Kasade and the retrogrodational part

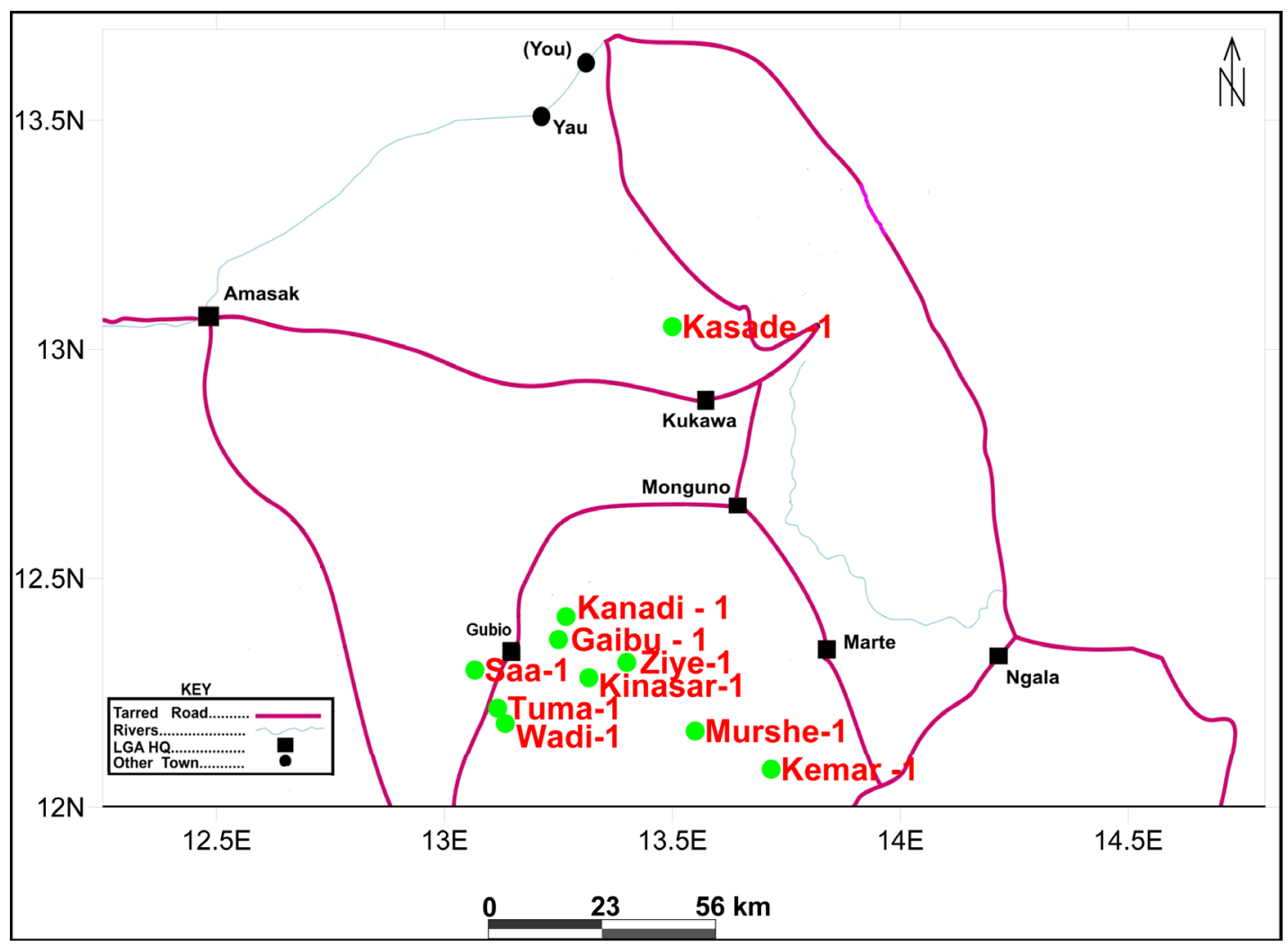

Figure 4. Map showing the location of hydrocarbon exploration wells in the Bornu Basin used for the computed geochemical data. 
Table 1. Summary of organic geochemical data of hydrocarbon exploration wells in the Bornu Basin. Lithostratigraphic division ([3] and proprietary source). The geochemical data are derived and recomputed from ${ }^{*}[8],^{* *}[10],{ }^{* * *}[13]$.

\begin{tabular}{|c|c|c|c|c|c|}
\hline WELL & FORMATION & SUB & TOC & TMAX & HI \\
\hline \multirow[t]{7}{*}{${ }^{* * *}$ Kasade 1} & Kerri-kerri & Upper & 0.02 & 332 & 50 \\
\hline & & Lower & 0.05 & 349 & 40 \\
\hline & Fika & Upper & av 0.82 & 424 & \\
\hline & & Lower & av 1.23 & 433 & 84 \\
\hline & Gongila & Retrogadation & av 1.01 & 438 & 128 \\
\hline & & Aggradation & av 0.77 & 436 & 93 \\
\hline & Yolde & & av 0.05 & 423 & 69 \\
\hline \multirow[t]{5}{*}{ Kinasar-1 } & Fika & Upper & 1.02 & 438 & 36 \\
\hline & & Lower & 0.7 & 469 & 44 \\
\hline & Gongila & Retrogadation & 0.7 & 437 & 95 \\
\hline & & Aggradation & 1.25 & 451 & 14 \\
\hline & Yolde & & 0.58 & 365 & 36 \\
\hline \multirow[t]{5}{*}{${ }^{* *}$ Gaibu-1 } & Fika & Upper & 0.92 & & \\
\hline & & Lower & 1.11 & $>1.1$ & \\
\hline & Gongila & Retrogadation & 0.87 & & \\
\hline & & Aggradation & 1.12 & & \\
\hline & Yolde & & 0.73 & & \\
\hline \multirow[t]{5}{*}{${ }^{* * *}$ Murshe-1 } & Fika & Upper & 1.17 & 438 & 133 \\
\hline & & Lower & 0.74 & 477 & 12 \\
\hline & Gongila & Retrogadation & 0.66 & 428 & 15 \\
\hline & & Aggradation & 0.65 & 488 & 12 \\
\hline & Yolde & & 0.71 & 368 & 11 \\
\hline \multirow[t]{5}{*}{${ }^{*}$ Kanadi-1 } & Fika & Upper & 0.73 & 448 & 28 \\
\hline & & Lower & 0.76 & 453 & 28 \\
\hline & Gongila & Retrogadation & 0.73 & 484 & 25 \\
\hline & & Aggradation & 0.79 & 467 & 18 \\
\hline & Yolde & & 0.51 & 468 & 30 \\
\hline \multirow[t]{5}{*}{ Saa-1 } & Fika & Upper & 0.92 & 462 & 15 \\
\hline & & Lower & 1.11 & 438 & 75 \\
\hline & Gongila & Retrogadation & 0.87 & 402 & 13 \\
\hline & & Aggradation & 1.12 & 453 & 26 \\
\hline & Yolde & & 0.73 & 474 & 27 \\
\hline \multirow[t]{5}{*}{${ }^{* * *}$ Ziye-1 } & Fika & Upper & 0.54 & 446 & 86 \\
\hline & & Lower & 2.15 & 459 & 77 \\
\hline & Gongila & Retrogadation & 0.6 & 519 & 24 \\
\hline & & Aggradation & 1.21 & 457 & 12 \\
\hline & Yolde & & 0.54 & 463 & 41 \\
\hline \multirow[t]{5}{*}{ Wadi-1 } & Fika & Upper & 1.23 & 432 & 35 \\
\hline & & Lower & 0.84 & 438 & 19 \\
\hline & Gongila & Retrogadation & 0.81 & 402 & 19 \\
\hline & & Aggradation & 0.75 & 453 & 39 \\
\hline & Yolde & & 0.78 & 474 & 33 \\
\hline
\end{tabular}


Table 2. Geochemical data from hydrocarbon exploration wells and shallow water wells from the fringes of Bornu Basin (Re-computed from [30]).

\begin{tabular}{|c|c|c|c|c|c|c|c|}
\hline \multirow[t]{2}{*}{ Well Name } & \multirow[t]{2}{*}{ Formation } & \multicolumn{2}{|l|}{ TOC } & \multicolumn{2}{|l|}{ Tmax } & \multicolumn{2}{|l|}{ HI } \\
\hline & & Av. wt $\%$ & Range wt\% & av. ${ }^{\circ} \mathrm{C}$ & Range ${ }^{\circ} \mathrm{C}$ & Av. mg/g & Range mg/g \\
\hline${ }^{*}$ Saa-1 & FIKA & 0.6192 & $0.15-0.84$ & 442.9286 & $415-469$ & 98.21429 & $33-145$ \\
\hline \multirow[t]{3}{*}{${ }^{*}$ Tuma-1 } & FIKA & 0.7922 & $0.3-1.19$ & 436.4444 & $420-458$ & 110.5556 & $45-156$ \\
\hline & GONGILA & 0.908 & $0.6-1.54$ & 487.6 & $461-526$ & 118.4 & $65-171$ \\
\hline & BIMA & 0.59 & $0.58-0.6$ & 459.5 & $458-461$ & 78.5 & $60-97$ \\
\hline \multirow[t]{3}{*}{${ }^{*}$ WADI-1 } & FIKA & 0.6867 & $0.49-096$ & 0.051667 & & 96 & $48-130$ \\
\hline & GONGILA & 0.465 & $0.29-0.62$ & 412.6667 & $369-458$ & 64.33333 & $40-121$ \\
\hline & BIMA & 0.46 & & 452 & & 120 & \\
\hline \multirow[t]{2}{*}{ *KINASAR-1 } & FIKA & 0.536 & $0.06-0.71$ & 445.6 & $439-451$ & 173.8 & $153-200$ \\
\hline & GONGILA & 0.3025 & $0.17-0.42$ & 397.5 & $338-455$ & 47.75 & $24-71$ \\
\hline \multirow[t]{3}{*}{${ }^{*} \mathrm{ZIYE}$} & FIKA & 0.785 & $0.66-0.85$ & 447 & $437-468$ & 112 & $102-124$ \\
\hline & GONGILA & 0.445 & $0.34-061$ & 411.25 & $361-486$ & 52.25 & $26-80$ \\
\hline & BIMA & 0.16 & $0.14-0.18$ & & & 73 & $7-139$ \\
\hline \multirow[t]{2}{*}{${ }^{* *}$ NGEL-1 } & FIKA & 0.6033 & $0.4-0.79$ & 426 & $421-432$ & 84.66667 & $66-115$ \\
\hline & GONGILA & 0.91 & & 418 & & 170 & \\
\hline${ }^{* *}$ DAK-1 & FIKA & 0.5475 & $0.38-0.7$ & 416.75 & $413-424$ & 63.5 & $26-93$ \\
\hline${ }^{* *}$ DAM-1 & FIKA & 0.525 & $0.46-0.61$ & 406 & $370-422$ & 55 & $41-73$ \\
\hline${ }^{* *}$ NA-1 & FIKA & 0.55 & $0.44-0.74$ & 382.25 & & 27.25 & $19-47$ \\
\hline \multirow[t]{2}{*}{${ }^{* *}$ FIK-1 } & FIKA & 0.585 & $0.41-0.76$ & 430 & $426-434$ & 59.5 & $46-73$ \\
\hline & GONGILA & 0.54 & & 428 & & 46 & \\
\hline \multirow[t]{2}{*}{${ }^{* *}$ MURF-1 } & FIKA & 0.56 & $0.48-0.64$ & 418 & $412-424$ & 66 & $63-69$ \\
\hline & GONGILA & 0.875 & $0.73-1.02$ & 412.5 & $403-422$ & 103.5 & $75-132$ \\
\hline
\end{tabular}

*Hydrocarbon exploration wells; ${ }^{* *}$ Shallow wells.

Table 3. Geochemical data from shallow water exploration wells from the fringes of the Bornu Basin (Re-computed from [35]).

\begin{tabular}{cccccccc}
\hline & FORMATION & DEPTH & TOC & SOM/TOC & SHC/TOC & VR \% & Kerogen Type \\
\hline BH1 & FIKA & $68-296$ & 0.84 & 27.41 & 4.81 & & \\
& GONGILA & $340-382$ & 0.90 & 35.83 & 5.20 & & \\
BH2 & FIKA & $50-210$ & 0.94 & 30.17 & 5.30 & & 111 or $1 \mathrm{~V}$ \\
BH3 & FIKA & $22-144$ & 1.03 & 14.74 & 2.06 & $0.36-0.41$ & $11-111$ \\
BH4 & GONGILA & $87-278$ & 0.80 & 55.10 & 3.90 & $0.40-0.42$ & \\
\hline
\end{tabular}

of the formation in Kinasar well (Table 1), thus suggesting that the organic matter is largely inert. Available Tmax data provide a glimpse into the maturity level of the organic matter. The Tmax values obtained from eight exploratory wells (Table 1 and Table 2) fall below the minimum of $430^{\circ} \mathrm{C}$ for oil generation in three of the wells (Murshe, Saa and Wadi). In these wells the Tmax values vary form $402^{\circ} \mathrm{C}-428^{\circ} \mathrm{C}$ (Table 1 ), which suggest that the organic matter is immature for hydrocarbon generation. But in the remaining tested portions in five wells, the formation appears to have received sufficient heat to generate hydrocarbon because the Tmax values vary from $436^{\circ} \mathrm{C}-526^{\circ} \mathrm{C}$. For example, in Tuma well (Table 2) the Tmax varies from $461^{\circ} \mathrm{C}-526^{\circ} \mathrm{C}$ which indicates availability of mature kerogen.

Within the Gongila Formation a Tmax reversal was reported [20], which suggests samples that have entered and left the oil window. This could be as a result of possible exhumation (which needs to be examined in our future study) in the basin. Geochemical information on the type of organic matter present in the formation is 
rather scanty. The data presented in Table 2 and Table 3 are derived from shallow water boreholes located at the fringes of Bornu Basin. According to [21] they indicate type II to III kerogen which suggests that the organic matter is derived from both marine and continental sources. Using Van Krevelyn type diagrams, [33] also showed that the kerogen is oil and gas prone (type II and III) although the low vitrinite reflectance $(0.40-0.42)$ implies that the organic matter has not yet reached the oil generation window. Outcrop study [7] of shales derived from the limestone quarry at Ashaka revealed the average TOC to be over $0.5 \mathrm{wt} \%$ while the SOM/TOC confirmed that the units contained adequate generating potential.

\subsubsection{Yolde}

Available geochemical data (Table 1) indicate that the organic matter in Yolde Formation within the tested area is enough ( $>0.51 \mathrm{wt} \%)$ for hydrocarbon generation. Likewise, the temperature the organic matter had been subjected to exceeded the diagenetic stage, but the HI appears generally too low except in Kasade-1 well (Table 1) for the generation of even gas.

\subsubsection{Bima}

In spite of the numerous strata containing shale within the Bima Formation as found in the ditch cuttings and wireline log of eight wells we have studied, the available geochemical information (Table 2) on the Bima Formation is too scanty to draw any meaningful conclusion. A further probe of the shales geochemically in Bima Formation is desirable.

\subsection{Possible Reservoir Rock}

Several possible reservoir beds exist within the various sand/sandstone units of nearly all the established lithostratigraphic units (Figure 2) in the Bornu Basin except that the orthodox source-reservoir-seal interplay has not been proved. [34] attempted a reservoir characterization and evaluation of depositional trend of sands of Gombe Formation to assess their petrophysical qualities as a potential reservoir unit for hydrocarbon accumulation in the Chad basin because the sand sequence directly overlies Fika Shale—a possible source rock [35] [8] [13] [36]. Their study [3] revealed that sand unit thicknesses within the formation vary between 32 and $225 \mathrm{~m}$; Net-to-gross ratio (NGR) values vary from 5.93\% - 94.34\%; average effective porosity from $14.88 \%$ - 34.74\%; average volume of shale from $12.11 \%$ - 36.65\%; average water saturation ranges from $3.83 \%-97.00 \%$; average hydrocarbon saturation values from 3.00\% - 96.17\%; and average permeability from $5903-90,836.5 \mathrm{mD}$. The porosity and permeability values are optimal for hydrocarbon accumulation. Elsewhere within the basin, the porosities are moderate to high at shallow and intermediate intervals (25\% to over $50 \%$ ) and reduces with increasing depth to as low as $3 \%$ [23].

\subsection{Possible Seals/Traps}

The three major tectonic events that affected the whole Mega-Chad Basin, particularly the Santonian compression and its consequent structural deformation, provide adequate stratigraphic and structural trapping conditions in the basin. The stratigraphic elements could consist of channel fills and lenses, which might have been caused by small scale progradational events in transgressive systems tracts. Pinchout and general sub-basin-ward thinning caused by either greater compaction in the deeper part of the basin, sediment starvation or basin inversion have been observed [28]. According to [37] trapping conditions against intrusive features (igneous or sedimentary origin) exist in the basin (Figure 3). Anticlinal, horst and grabben as well as growth fault conditions (Figure 5 and Figure 6) suitable for trapping hydrocarbon are common structural traps in the basin.

\section{Discussion and Conclusions}

The foregoing assessment of the potential geological factors that could produce the appropriate petroleum habitat in the Bornu Basin indicates that the ingredients for the formation and retention of petroleum are, by and large, present in the basin. However, a major drawback of this study is paucity of data that limits the understanding of the basin through knowledge gaps. In spite of this there are indications of high prospects based on existing limited information that can be followed up.

In terms of source rock availability in the basin, most of the litho-units studied in the Fika, Yolde, Gongila 


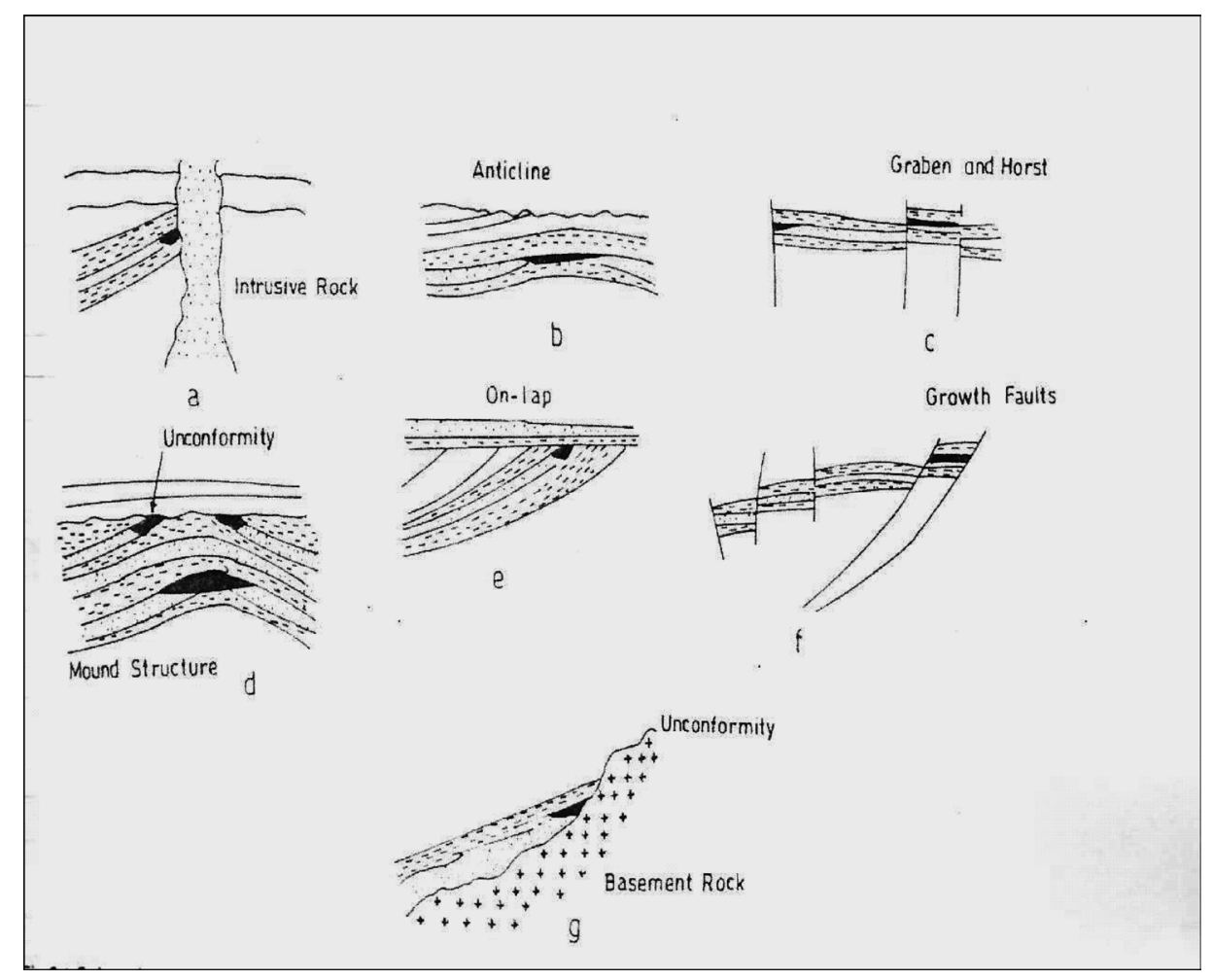

Figure 5. Subsurface structural styles and traps deduced from seismic lines in the Bornu basin, (a) "Hydrocarbon" entrapment updip against intrusive rock; (b) Anticlinal trap; (c) Graben and horst structure; (d) Unconformity and mound structural trap; (e) Onlap; (f) Growth fault; (g) Trapping against basement rock (Adapted from [37]).

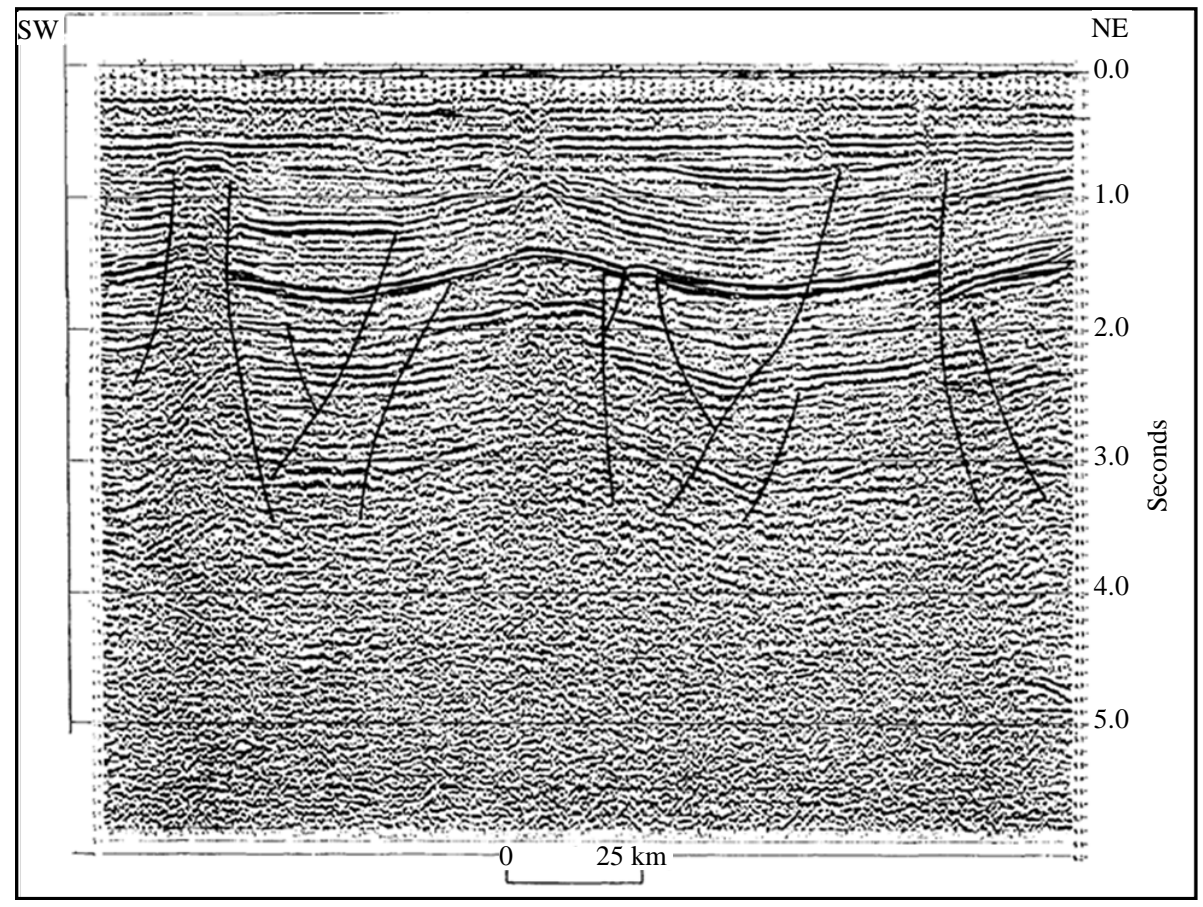

Figure 6. Structural style in the Bornu basin [5] showing anticlinal structures, toplaps and downlapping surfaces including trapping conditions against intrusive features that could serve as stratigraphic traps. 
and Bima Formations tend to contain sufficient organic matter (0.54 wt $\%-2.15 \mathrm{wt} \%)$ but the low HI values of the organic matter (Table 1) suggest that it may be inert except in a few intervals. Available Tmax values (Table 1 and Table 2) for the studied litho-units can be divided into three groups on the basis of thermal maturation the Tmax traditionally symbolizes. The first group falls within a Tmax range of $365^{\circ} \mathrm{C}-428^{\circ} \mathrm{C}$ accommodating $20.6 \%$ of the data in Table 1 ; the second group has a range of $433^{\circ} \mathrm{C}-463^{\circ} \mathrm{C}$ containing $52.9 \%$ of the Tmax values; and the third group lies within a range of $467^{\circ} \mathrm{C}-519^{\circ} \mathrm{C}$ with $26.5 \%$ of the Tmax data in Table 1 . This simple analysis indicates that majority of the samples (Table 1) of the studied potential source rocks within Fika, Yolde, Gongila and Bima having Tmax of $433^{\circ} \mathrm{C}-463^{\circ} \mathrm{C}$ fall within the oil generation window. It is noteworthy that the third group of analyzed samples that record very high Tmax (467\% and above) come from Gongila, Yolde and Lower Fika Formations. The implication of this is that any shale with sufficient organic matter in the three formations must have received so much heat that it would transit to the oil-gas transition zone. This may be the scenario that produced the gas discovered in the Kinasar well in the basin.

Two significant inferences can be drawn from the totality of geochemical evidence on the quantity, quality and maturation levels of the organic matter in the tested shale samples of Fika, Yolde, Gongila and Bima Formations in the Borm Basin. The first is that these potential source rocks (i.e. the four formations) generally contain sufficient kerogen materials possibly of both marine and continental sources. The second is that some portions of the tested shales in the various formations might have attained oil and gas generation window as suggested by their Tmax values discussed earlier.

Much of the shales in the Kerri-Kerri Formation are yet to be subjected to geochemical studies to assess their possible source rock characteristics, probably because they are Tertiary in age. Oil sourced from Tertiary lacustrine shale occurs in the Doba and Doseo basins within the Mega-Chad Basin. It must not be ruled out therefore that the shales in the Kerri-Kerri Formation are not mature for hydrocarbon generation.

With the established evidence of occurrence of source rocks for hydrocarbon generation in the Bornu Basin, what remains to prove is the availability of other requisite factors or conditions for hydrocarbon accumulation and retention, which consist mainly of kerogen maturation conditions, as well as reservoir rocks and traps/seals. Possible reservoir rocks, mainly sand/sandstone units, occur in all the formations penetrated so far. However, only those of the Gombe Formation, which overlies the Fika Formation (a possible source rock) has been subjected to petrophysical studies [34] and is found to have favourable porosity and permeability for hydrocarbon accumulation. Although the petrophysical characteristics of Bima Formation have not been studied, available ditch cuttings and wireline log motifs have revealed that the formation consists, at least in part, of alternating sandstone and shale beds particularly in the upper part. Unfortunately, the Bima Formation has not been penetrated in its entirety. Only the upper part has been drilled. The deepest exploratory well, Herwa-1 went as far as $4715 \mathrm{~m}$ deep. Deep drilling is desirable in the Bornu basin since Bima on account of its sandstone/shale lithology can serve both as source and reservoir rocks.

On the basis of experience derived from the Doseo, Doba, and Termit basins, where petroleum has been found in deep Cretaceous and relatively shallow Tertiary sequences one cannot rule out the occurrence of petroleum in the lower Bima, more so that emerging data suggest that the Bima also contains shale beds which can serve as source rock.

\section{Acknowledgements}

The authors of this paper sincerely thank Petroleum Technology Development Fund (PTDF) for funding the ongoing research in the Bornu Basin. Our sincere thanks also go to other anonymous reviewers for improving the quality of the paper.

\section{References}

[1] Falconer, J.D. (1911) The Geology and Geography of Northern Nigeria. MacMillan, London, 286.

[2] Cratchley, C.R. (1960) Geophysical Survey of the Southwestern Part of the Chad Basin. CCTA Conference on "Geology”, Kaduna.

[3] Popoff, M. (1988) Du Gondwana a I’Atlantique sud: Les connexions du foss de la avec les basins du Nord-Est b\&lien jusqu'a l'ouverture du golfe de Guinee au Critac inferieur. Journal of African Earth Sciences, 7, 409-431.

[4] Ayoola, E.O., Amaechi, M. and Chukwu, R. (1982) Nigeria’s Newer Petroleum Exploration Provinces Benue, Chad and Sokoto Basin. Journal of Mining and Geology, 19, 72-85. 
[5] Avbovbo, A.A., Ayoola, E.O. and Osahon, G.A. (1986) Depositional and Structural Styles in the Chad Basin of Northeastern Nigeria. American Association of Petroleum Geologist Bulletin, 70, 1787-1798.

[6] Okosun, E.A. (1995) Review of Geology of Bornu Basin. Journal of Mining and Geology, 31, 113-122.

[7] Petters, S.W. and Ekweozor, C.M. (1982) Petroleum Geology of the Benue Trough and Southeastern Chad Basin, Nigeria. American Association of Petroleum Geologists Bulletin, 66, 1141-1149.

[8] Olugbemiro, R.O., Ligouis, B. and Abaa, S.I. (1997) The Cretaceous Series in the Chad Basin, NE Nigeria Source Rock Potential and Thermal Maturity. Journal of Petroleum Geology, 20, 51-58. http://dx.doi.org/10.1111/j.1747-5457.1997.tb00755.x

[9] Obaje, N.G., Attah, D.O., Opeloye, S.A. and Moumouni, A. (2006) Geochemical Evaluation of the Hydrocarbon Prospects of Sedimentary Basins in Northern Nigeria. Geochemical Journal, 40, 227-243. http://dx.doi.org/10.2343/geochemj.40.227

[10] Moumouni, A., Obaje, N.G., Nzegbuna, A.I. and Chaanda, M.S. (2007) Bulk Geochemical Parameters and Biomarker Characteristics of Organic Matter in Two Wells (Gaibu-1 and Kasade-1) from the Bornu Basin: Implications on the Hydrocarbon Potentials. Journal of Petroleum Sciences and Engineering, 58, 275-282. http://dx.doi.org/10.1016/j.petrol.2007.01.004

[11] Ziegler, P.A. (1990) Geological Atlas of Western and Central Europe. 2nd Edition, Shell Internationale Petroleum Mij. B.V. and Geological Society, London, 239 p.

[12] Guiraud, R., Issawi, B. and Bosworth, W. (2001) Phanerozic History of Egypt and Surrounding Areas. In: Ziegler, P.A., Cavazza, W., Robertson, A.H.F. and Crasquin-Soleau, S., Eds., Peri-Tethys Memoir 6: Peri-Tethyan Rift/Wrench Basins and Passive Margins, Vol. 186, Memoires du Museum national d'Histoire naturelle, Paris, 469-509.

[13] Obaje, N.G., Wehner, H., Scheeder, G., Abubakar, M.B. and Jauro, A. (2004) Hydrocarbon Prospectivity of Nigeria’s Inland Basins: From the Viewpoint of Organic Geochemistry and Organic Petrology. American Association of Petroleum Geologists Bulletin, 88, 325-353.

[14] Burke, K.C. (1976) The Chad Basin: An Active Intra-Continental Basin. Tectonophysics, 36, 197-206. http://dx.doi.org/10.1016/0040-1951(76)90016-0

[15] Genik, G.J. (1993) Petroleum Geology of Cretaceous-Tertiary Rift Basins in Niger, Chad and Central African Republic. American Association of Petroleum Geologists Bulletin, 77, 1405-1434.

[16] Alalade, B. and Tyson, R.V. (2010) Hydrocarbon Potential of the Late Cretaceous Gongila and Fika Formations, Bornu (Chad) Basin, NE Nigeria. Journal of Petroleum Geology, 33, 339-353.

[17] Fairhead, J.D. (1988) Mesozoic Plate Tectonic Reconstructions of the Central South Atlantic Ocean: The Role of the West and Central African Rift System. Tectonophysics, 155, 181-191. http://dx.doi.org/10.1016/0040-1951(88)90265-X

[18] Browne, S.E. and Fairhead, J.D. (1983) Gravity Study of the Central African Rift System: A Model of Continental Disruption 1. The Ngaoundere and Abu Gabra Rifts. Tectonophysics, 94, 187-203. http://dx.doi.org/10.1016/0040-1951(83)90016-1

[19] Guiraud, R., Doumnang, J.C., Carretier, S. and Dominguez, S. (2000) New Evidence for a 6000 km Length NW-SEStriking Lineament in Northern Africa: The Tibesti Lineament. Journal of the Geological Society (London), 157, 897900. http://dx.doi.org/10.1144/jgs.157.5.897

[20] Guiraud, R., Bosworth, W., Thierry, J. and Delplanque, A. (2005) Phanerozoic Geological Evolution of Northern and Central Africa: An Overview. Journal of African Earth Sciences, 43, 83-143. http://dx.doi.org/10.1016/j.jafrearsci.2005.07.017

[21] Warren, M.J. (2009) Tectonic Inversion and Petroleum System Implications in the Rifts of Central Africa. Frontiers and Innovation, CSPG CSEG CWLS Convention, Calgary, Alberta, 4-8 May 2009, 4 p.

[22] Adegoke, O.S., Agumanu, A.E., Benkhelil, M.J. and Ajayi, P.O. (1986) New Stratigraphic, Sedimentologic and Structural Data on the Kerri-Kerri Formation, Bauchi and Bornu States, Nigeria. Journal of African Earth Sciences, 5, 249-277.

[23] Carter, J.D., Barber, W., Tait, E.A. and Jones, G.P. (1963) The Geology of Parts of Adamawa, Bauchi and Borno Provinces in Northeastern Nigeria. Geological Survey of Nigeria Bulletin, 30, 1-108.

[24] Onuoha, K.M. (1999) Structural Features of Nigeria’s Coastal Margin: An Assessment Based on Age Data from Wells. Journal of African Earth Sciences, 29, 485-499. http://dx.doi.org/10.1016/S0899-5362(99)00111-6

[25] Tissot, B. and Welte, D.H. (1978) Petroleum Formation and Occurrence. Springer-Verlag, Berlin, 538 p. http://dx.doi.org/10.1007/978-3-642-96446-6

[26] Espitalie, J., Laporte, J.L., Madec, M., Marquis, V., Leplat, P., Paulet, J. and Boutefeu, A. (1977) Methode rapid de caracterisation des roches mere, de leur potential petrolier et de leur degre d'evolution. Rev. l'Inst. Franc.du Petroleum, 
32, 23-42.

[27] Espitalie, J. (1986) Use of Tmax as a Maturation Index for Different Types of Organic Matter. Comparison with Vitrinite Reflectance. In: Burrus, J., Ed., Thermal Modelling in Sedimentary Basins, Editions Technip, Paris, 475-496.

[28] Nwaezeapu, R.U. (1994) Petroleum Exploration Challenges in the Chad Basin. The Technical Session Meeting of the Maiduguri Chapter of the NMGS, 37 p.

[29] Ejedawe, J.E., Coker, S.J.L., Lambert-Aikhionbare, D.O., Alofe, K.B. and Adoh, F.O. (1984) Evolution of Oil-Generative Window and Oil and Gas Occurrence in Tertiary Niger Delta Basin. American Association of Petroleum Geologists Bulletin, 68, 1744-1751.

[30] Nwankwo, C.N. and Ekine, A.S. (2010) Geothermal Gradients in the Chad Basin, Nigeria, from Bottom Hole Temperature Logs. Scientia Africana, 9, 37-45.

[31] Nwankwo, C.N., Cyril, N., Ekine, A.S. and Nwosu, L.I. (2009) Estimation of the Heat Flow Variation in the Chad Basin Nigeria. Journal of Applied Sciences and Environmental Management, 13, 73-80.

[32] Wilson, M. and Guiraud, R. (1992) Magmatism and Rifting in Western and Central Africa, from Late Jurassic to Recent Times. Tectonophysics, 213, 203-225. http://dx.doi.org/10.1016/0040-1951(92)90259-9

[33] Idowu, J.O. (1996) Petroleum Formation and Occurrence in the Southwestern Chad Basin, Nigeria. (Proprietary).

[34] Adepelumi, A.A., Alao, O.A. and Kutemi, T.F. (2011) Reservoir Characterization and Evaluation of Depositional Trend of the Gombe Sandstone, Southern Chad Basin Nigeria. Journal of Petroleum and Gas Engineering, 2, 118-131.

[35] Idowu, J.O. and Ekweozor, C.M. (1989) Petroleum Geochemistry of Some Upper Cretaceous Shales from Upper Benue Trough and South-Western Chad Basin, Nigeria. Journal of Mining and Geology, 25, 1-2.

[36] Adepelumi, A.A., Falebita, D.E., Olorunfemi, A.O. and Olayoriju, S.I. (2010) Source-Rock Investigation of the Turonian-Maastrichtian Fika Shale from Wireline-Logs, Chad Basin, Nigeria. International Journal of Petroleum Science and Technology, 4, 19-42.

[37] Odusina, A.S., Mubarak, O., Beka, F.T. and Nwangu, U. (1983) Geology and Petroleum Potential of the Nigerian Sector of the Chad Basin. Research Bulletin iii, Exploration Research Section (R\&D), Project No. ER/RD/43, NNPC Port-Harcourt, Nigeria, 47 p. 
Scientific Research Publishing (SCIRP) is one of the largest Open Access journal publishers. It is currently publishing more than 200 open access, online, peer-reviewed journals covering a wide range of academic disciplines. SCIRP serves the worldwide academic communities and contributes to the progress and application of science with its publication.

Other selected journals from SCIRP are listed as below. Submit your manuscript to us via either submit@scirp.org or Online Submission Portal.
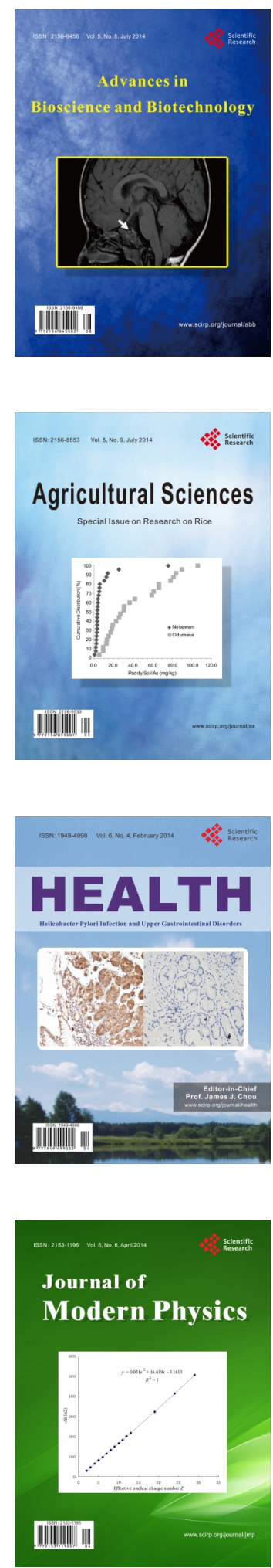
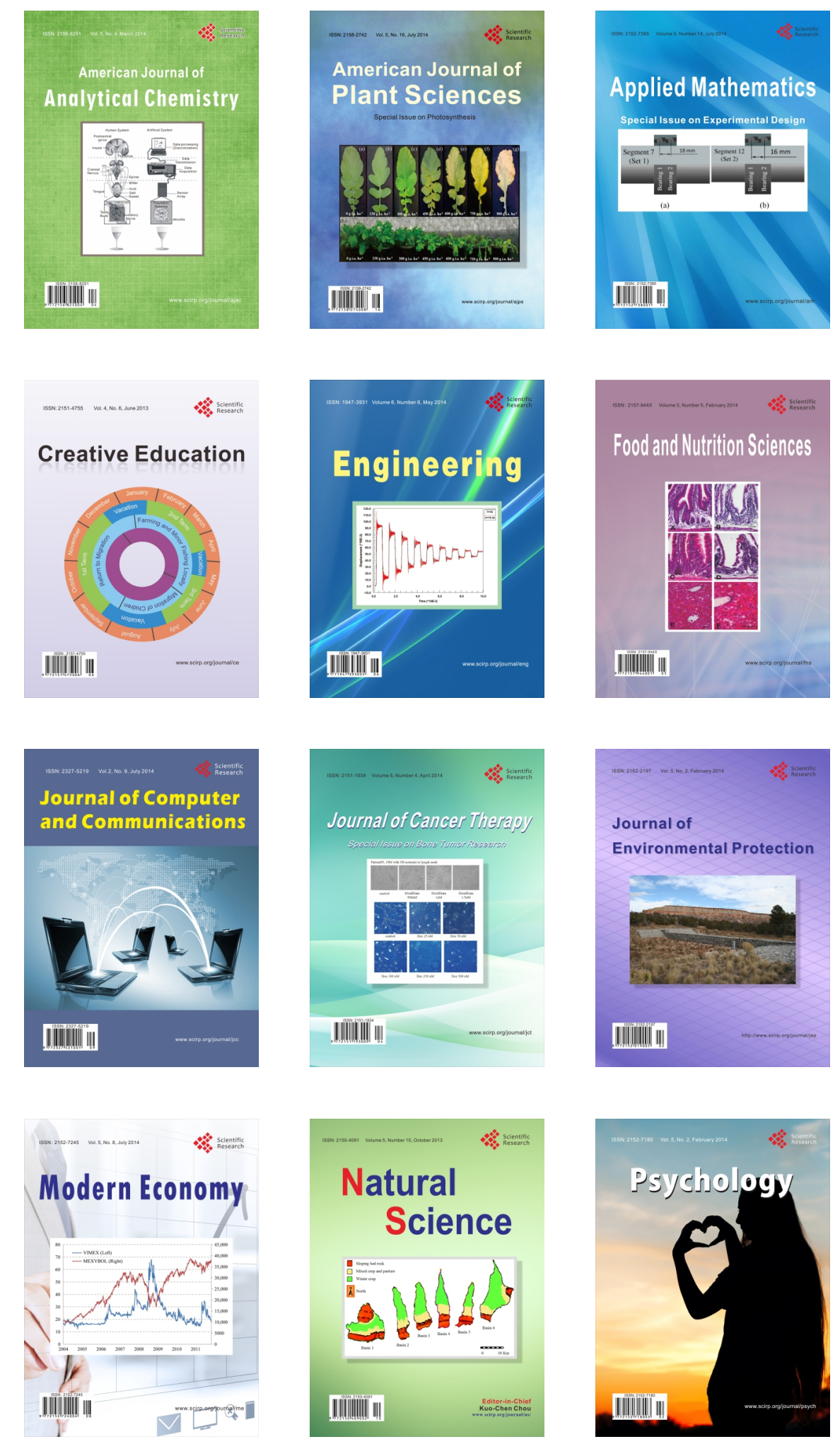